\title{
EVERYDAY GOALS, RELIGIOUS MOTIVATIONS, AND WELL-BEING: THE MEDIATING ROLE OF EMOTIONS
}

\author{
Tamás MARTOS, Viola SALLAY, Anikó KÉZDY \\ Institute of Mental Health, Semmelweis University \\ Ulloi ut 26, Budapest, 1085, Hungary \\ E-mail: martos@mental.usn.hu
}

\begin{abstract}
Building on previous conceptualization of different religious reasons for goal striving we tested whether normative religious motivation (NRM, e.g., following church norms) and transcendental religious motivation (TRM, e.g., striving for spiritual communion with the transcendent) for personal projects predict positive and negative emotions as well as well-being indices. In this cross-sectional study 396 Hungarian adults rated their most characteristic everyday goals from the aspect of their religious reasons (NRM and TRM) and the positive and negative emotions associated to them, and also scored their satisfaction, level of self-actualization, and meaningfulness regarding these goals. Results showed that NRM was associated with negative emotions, while TRM was connected more to positive emotions. Moreover, emotional meaning of the projects mediated between the religious reasons for projects and well-being.
\end{abstract}

Key words: goals, personal projects, religious motivation, emotions, well-being

Goals are highly personalized cognitive constructs representing possible future states and events that people strive for or sometimes try to avoid (Austin, Vancouver, 1996; Emmons, 1996). Personal projects are especially close to everyday functioning, through linking central aspects of the self, for example, core values and environmental challenges and possibilities (Little, 2007). Moreover, several characteristics of goals and personal projects were found to be associated with well-being and mental health as well, such as self-concordance (Sheldon, 2001) or approach and avoidance tendencies (Elliot, Friedman, 2007).

Acknowledgment: This research was partly supported by the Hungarian Scientific Research Fund (OTKA) under the grant number PD 105685.
In line with these conceptualizations, psychology of religion also applied the goal construct framework in search of possible mediators in the long debated religiousnesswell-being connection. Two characteristic ways emerged, one that defines religious/ spiritual goals by their content (e.g., Emmons, 1999), and another that focuses on the subjective religious/spiritual meaning of the goals, regardless of their content, that is, the sanctification of the goals (Mahoney, Pargament et al., 2005; Tix, Frazier, 2005). Building on and extending these considerations, Martos, Kézdy and Horváth-Szabó (2011) suggested that personal projects may be motivated by religious reasons as well, and that these motivations may be at least twofold in their nature: normative and transcendental. Normative religious motivation

DOI: $10.21909 /$ sp.2013.03.638 
(NRM) was defined as an adjustment of personal projects to external, normative religious references, while in transcendental religious motivation (TRM) the person's reason for pursuing everyday goals is his/her relationship with "the sacred".

In a series of empirical studies Martos and colleagues (2011) showed that NRM and TRM were interrelated, but they associated differently with constructs of religiosity (sanctification of projects, types of religious self-regulation, intrinsic-extrinsic religiosity, and basic religious attitudes). Furthermore, TRM was associated with autonomous regulation of personal projects while NRM was associated with controlled regulation, and NRM predicted negatively and TRM predicted positively indices of well-being (satisfaction, self-actualization and meaning). These links were partially mediated by regulation types, where TRM was associated with an autonomous way of goal pursuit (i.e., because of the joy associated with the goal or because the goal seems personally meaningful) while NRM was linked to more controlled ways of self-regulation (i.e., the pursuit of external rewards or a sense of fulfilling obligations as a reason for the goal; c.f. Sheldon, 2001).

In the present study we tested an alternative mediator, that is, the emotions associated with the projects. Religion is one of the most complex human phenomena, involving the cognitive and the affective side of the human existence. Religious and spiritual experiences are rich in both positive and negative emotions (Emmons, 2005), while religions themselves often try to regulate (i.e., prescribe or restrict) certain emotions toward God/the Holy and other people (Silberman, 2003). Since NRM stems from a more rigid, controlled way of being religious
(Martos et al., 2011), we assume that NRM projects will be more characterized by negative emotions, such as guilt or sadness. On the other hand, TRM for everyday projects is associated with an intrinsic, open-minded way of religiousness; therefore the projects motivated by TRM may evoke more positive emotions, such as gratitude or awe, on the level of the projects, that is, in the everyday experiences of project striving. Finally, drawing on these assumptions we hypothesize that project emotions may mediate between NRM, TRM, and well-being outcomes; the nature and the extent of religious/spiritual motivations of the projects will have an impact on the emotional experience accompanying the projects, and these experiences will, in turn, orient the well-being of the individual. Specifically, NRM would predict lower, and TRM higher well-being through negative and positive emotions, respectively.

\section{METHOD}

\section{Sample and Procedure}

We carried out a cross-sectional questionnaire study on a convenience sample from the middle part of Hungary. Questionnaires were distributed by students of an introductory psychology of personality course as partial fulfillment of the course requirements. Students were instructed to collect data among their friends and relatives. Confidentiality and anonymity were guaranteed. 396 participants, 161 males (mean age 28.6 \pm 11.6 years) and 235 females (mean age $27.9 \pm 11.8$ years) took part in the study. The denominational background was: Catholic 268 (67.7\%), other Christian 41 (13.4\%), religious but not belonging to any 
denomination $32(8.1 \%)$, non religious 54 $(13.6 \%)$, with data missing in one case. Importance of religion was: not important in 72 cases $(18.2 \%)$, somewhat important and important in 146 cases in both categories $(36.9 \%)$, and very important in 30 cases $(7.6 \%)$ with data missing in two cases.

\section{Measures}

Personal projects. Personal project assessment was conducted according to the procedure developed by Little (1983). First, participants were asked to write a list of their current personal projects, that is, "your current goals which you are already taking steps to achieve". Participants were then asked to select the four most characteristic projects in their everyday life. Finally, these four projects were evaluated on a set of predefined aspects using a six-point scale $(0=$ does not describe the project at all to $5=$ fully describes the project). Normative and transcendental religious motivations for the projects were assessed according to the procedure described in Martos et al. (2011). Introduced by the question "Why are you working on this project?", two possible reasons were provided for further evaluation: "Because my denomination or church expects me to work on this project" represented normative religious motivation (NRM), and "Because I can experience communion with God/the transcendent through this project" represented transcendental religious motivation (TRM). In addition, participants evaluated to what extent their projects were associated with five positive and five negative emotions: peaceful, guilty, grateful, scared, curious, angry, enthusiastic, doubtful, awesome and sad. Alpha coefficients were calculated for NRM and TRM
( 0.862 and 0.859 , respectively), and for the aggregated negative and positive emotions (NE and PE, alphas 0.873 and 0.837 , respectively).

Satisfaction With Life Scale (SWLS). SWLS measures general satisfaction with one's life (Diener et al., 1985). Items were scored on a 7-point Likert-scale yielding from "Strongly disagree" (1) to "Strongly agree" (7). Internal consistency was excellent in our sample (alpha 0.863).

Short Index of Self-Actualization (SISA). This 15-item scale (Jones, Crandall, 1986) was developed to measure the humanistic concept of self-actualization: the acceptance of one's emotions and living in accordance with one's potentials, as well as authentic and loving relationships with others. Agreement with the statements is scored on a 4-point Likert scale ranging from "Disagree" (1) to "Agree" (4). The scale had an acceptable alpha of 0.601 .

Purpose in Life Test, 10-item version (PIL10). To assess meaning in life the shortened, 10 -item version of the Purpose in Life Test was used (Crumbaugh, Macholick, 1964; Konkolÿ Thege, Martos, 2006). Items refer to the person's sense of meaningfulness in life and are scored on a 7-point Likert-scale, always anchored by two statements with opposite meaning (alpha 0.868).

\section{RESULTS}

Means, SD-s and correlations for the variables in the study are presented in Table 1 . NRM and TRM correlated positively ( $\mathrm{rs}=$ $.57, \mathrm{p}<.001$ ). Both NRM and TRM correlated positively with positive and negative emotions, with the strongest coefficient between TRM and negative emotions (rs between 0.20 and 0.36 , all ps $<.001$ ). There was 
only one negative significant relationship between NRM and satisfaction $(\mathrm{r}=-0.16, \mathrm{p}<$ $.01)$. Generally, positive emotions associated with the project correlated positively, while negative emotions negatively with well-being measures $(\mathrm{ps}<.001)$.

The complex relationship of the variables was tested using the proposed causal model via path analysis (Statistica 8.0, StatSoft Inc., Tulsa, Oklahoma). The model parameters were estimated using maximum likelihood estimator. In the first step a full regression model was built with NRM and TRM as covarying exogenous variables, with negative and positive emotions as mediators, and SWLS, SISA and PIL as outcome variables. Error terms of the negative and positive emotions scores and those of the well-being measures were set to covary. During a stepwise procedure nonsignificant paths $(\mathrm{p}<.05)$ were removed. The final model (see Figure 1) indicated acceptable fit $(\mathrm{X} 2(10)=$ $14.56, \mathrm{p}=.15$, ns., $\mathrm{NFI}=.984, \mathrm{CFI}=.995$,
RMSEA $=.026,95 \% \mathrm{CI}=.00-.052$ ). This final model accounted for $8.3,12.4$ and $8.7 \%$ of the variance in SWLS, SISA and PIL, respectively.

Results showed considerable covariance between NRM and TRM. Moreover, NRM was in positive association with negative emotions in the projects (beta $=.15, \mathrm{p}<.05$ ), while TRM related positively to both negative and positive emotions (betas $=.16$ and .37 , respectively, both ps $<.01$ ). Negative emotions predicted well-being indicators negatively, while positive emotions predicted them positively. There was also a direct negative path from NRM to self-actualization (beta $=-.16, p<.05)$.

\section{DISCUSSION}

These results give support to our initial assumptions about the potential emotional consequences of religious cognitions in everyday projects. Specifically, projects with

Table 1. Descriptive statistics and zero-order Pearson correlations for variables in the study

\begin{tabular}{|l|l|c|c|c|c|c|c|c|c|c|c|}
\hline & & & & \multicolumn{6}{|l|}{ zero-order correlations } & \multicolumn{1}{l|}{} \\
\hline & Variables & alpha & M & SD & 1 & 2 & 3 & 4 & 5 & 6 & 7 \\
\hline 1 & NRM & 0.888 & 0.62 & 1.09 & & & & & & & \\
\hline 2 & TRM & 0.872 & 0.96 & 1.35 & $0.57^{* * *}$ & & & & & & \\
\hline 3 & NE-P & 0.809 & 1.54 & 0.84 & $0.20^{* * *}$ & $0.23^{* * *}$ & & & & & \\
\hline 4 & PE-P & 0.730 & 2.55 & 0.87 & $0.21^{* * *}$ & $0.36^{* * *}$ & 0.01 & & & & \\
\hline 5 & Satisfaction & 0.851 & 2.85 & 0.32 & $-0.13^{*}$ & -0.02 & $-0.36^{* * *}$ & $0.16^{* *}$ & & & \\
\hline 6 & $\begin{array}{l}\text { Self- } \\
\text { actualization }\end{array}$ & 0.602 & 4.88 & 1.21 & -0.05 & -0.09 & $-0.29^{* * *}$ & 0.05 & $0.28^{* * *}$ & & \\
\hline 7 & Meaning & 0.630 & 53.64 & 8.69 & 0.04 & 0.08 & $-0.23^{* * *}$ & $0.17^{* *}$ & $0.45^{* * *}$ & $0.61^{* * *}$ & \\
\hline
\end{tabular}

Note: $\mathrm{NRM}=$ Normative Religious Motivation, $\mathrm{TRM}=$ Transcendental Religious Motivation, NE-P = Negative Emotions in Projects, PE-P = Positive Emotions in Projects, Satisfaction $=$ Satisfaction with Life Scale, Self-actualization $=$ Short Index of SelfActualization, Meaning $=$ Purpose in Life Test (10-item version) $\mathrm{N}=396 ;+\mathrm{p}<.10, * \mathrm{p}<.05, * * \mathrm{p}<.01, * * * \mathrm{p}<.001$ 


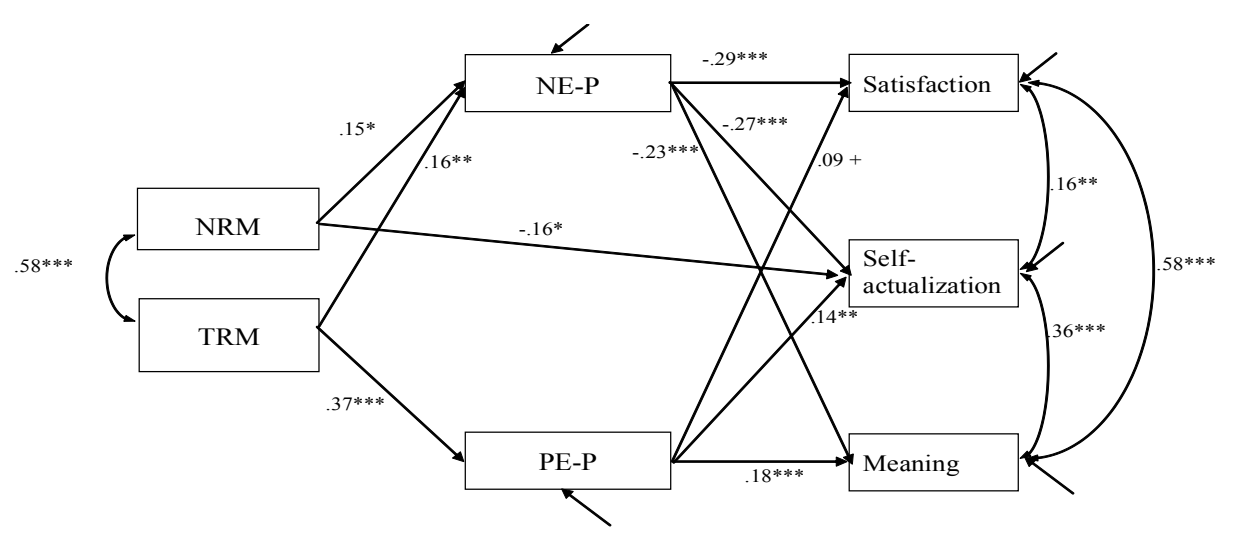

Note: NRM $=$ Normative Religious Motivation, $\mathrm{TRM}=$ Transcendental Religious Motivation, NE-P = Negative Emotions in Projects, $\mathrm{PE}-\mathrm{P}=$ Positive Emotions in Projects, Satisfaction $=$ Satisfaction with Life Scale, Self-actualization $=$ Short Index of Self-Actualization, Meaning $=$ Purpose in Life Test $(10$-item version $)$

$+\mathrm{p}<.10, * \mathrm{p}<.05, * * \mathrm{p}<.01, * * * \mathrm{p}<.001$

Figure 1. Final path model

NRM, that is, religious motivation based primarily on normative, external agents associated more with negative emotions (e.g., guilt and anger), while projects with TRM based on transcendental, spiritual reasons, were associated more with positive emotions (e.g., peace and gratitude). Interestingly, however, TRM was connected also to NE, although to a weaker extent, indicating that religiously motivated projects, especially those with TRM, have higher emotional significance for the person, and they are probably also emotionally more sophisticated than "nonreligious" projects.

On the whole, our assumption that the emotions associated with religious motivation may mediate between religiousness and well being, received support in the results.
However, NRM and TRM showed different potential in predicting well-being: NRM was associated with negative emotions and, as a potential consequence, with lower well-being, while TRM related positively to wellbeing mainly through its potential to evoke positive emotions. Finally, our results once again confirmed the results in the Martos et al. (2011) study that NRM may have a direct negative impact on self-actualization tendencies, probably because it is a sign that the person adjusts himself mainly to external authorities and not to more self-congruent reasons.

Certain limitations of our study also have to be taken into consideration. Most importantly, the cross-sectional nature of the design and the non-representative convenience 
sampling may limit the generalizability of our results.

In sum, our study shows that religiousness may have an impact on cognitions of everyday goals as well as on their emotional meaning, and, this way, it may foster but sometimes also hinder positive functioning and well-being.

Received March 10, 2013

\section{REFERENCES}

AUSTIN, J.T., VANCOUVER, J.B., 1996, Goal constructs in psychology: Structure, process, and content. Psychological Bulletin, 120, 338-375.

CRUMBAUGH, J.C., MAHOLICK, L.T., 1964 , An experimental study in existentialism: The psychometric approach to Frankl's concept of noogenic neurosis. Journal of Clinical Psychology, 20, 200207.

EMMONS, A.R., 2005, Emotion and religion. In: R.F., Paloutzian, C.L., Park (Eds.), Handbook of the psychology of religion and spirituality (pp. 235-252). New York: Guilford Press.

DIENER, E., EMMONS, R.A., LARSEN, R.J., GRIFFIN, S., 1985, The Satisfaction With Life Scale. Journal of Personality Assessment, 49, 71-75.

ELLIOT, A.J., FRIEDMAN, R., 2007, Approachavoidance: A central characteristic of personal goals In: B.R. Little, K. Salmela-Aro, S.D. Phillips (Eds.), Personal project pursuit. Goals, action and human flourishing (pp. 97-118). Mahwah: Lawrence Erlbaum.

EMMONS, R.A., 1996, Motives and life goals. In: S. Briggs, R. Hogan, J.A. Johnson (Eds.), Hand- book of personality psychology (pp. 485-512). San Diego: Academic Press.

EMMONS, R.A., 1999, The psychology of ultimate concerns: Motivation and spirituality in personality. New York: Guilford Press.

JONES, A., CRANDALL, R. 1986, Validation of a short index of self-actualization. Personality and Social Psychology Bulletin, 12, 63-73.

KONKOLŸ THEGE, B. MARTOS, T., 2006, Az Életcél Kérdőív magyar változatának jellemzői. [Psychometric characteristics of the Hungarian version of the Purpose in Life Test]. Mentálhigiéné és Pszichoszomatika, 7, 153-170.

LITTLE, B.R., 2007, Prompt and circumstances: The generative contexts of Personal Project Analysis. In: B.R. Little, K. Salmela-Aro, S.D. Phillips (Eds.), Personal project pursuit. Goals, action and human flourishing (pp. 3-50). Lawrence Erlbaum: Mahwah.

MAHONEY, A., PARGAMENT, K.I., COLE, B., JEWELL, T., MAGYAR, G.M., TARAKESHWAR, N., MURRAY-SWANK, N., PHILLIPS, R.E., 2005, A higher purpose: The sanctification of strivings in a community sample. International Journal for the Psychology of Religion, 15, 239-262.

SHELDON, K.M., 2001, The self-concordance model of healthy goal striving: When personal goals correctly represent the person. In: P. Schmuck, K.M. Sheldon (Eds.), Life-goals and well being. Towards a positive psychology of human striving (pp. 18-36). Seattle: Hogrefe and Huber.

SILBERMAN, I., 2003, Spiritual role modeling: The teaching of meaning systems. International Journal for the Psychology of Religion, 13, 175.

TIX, A.P., FRAZIER, P.A., 2005, Mediation and moderation of the relationship between intrinsic religiousness and mental health. Personality and Social Psychology Bulletin, 31, 295-306. 


\section{KAŽDODENNÉ CIELE, NÁBOŽENSKÁ MOTIVÁCIA A DUŠEVNÁ POHODA: MEDIAČNÁ ÚLOHA EMÓCIÍ}

T. M a r tos, V. S a 11 a y, A. Ké zdy

Súhrn: Na základe predchádzajúcich konceptov rozličných náboženských dôvodov pre snahu dosiahnut' ciel' sme testovali, či normatívna náboženská motivácia (NRM, napr. dodržiavanie náboženských noriem) a transcendentná náboženská motivácia (TRM, napr. snaha o duchovnú jednotu s transcendentnom) predikujú pri osobných projektoch pozitívne a negatívne emócie ako aj ukazovatele duševnej pohody. V tejto prierezovej štúdii 396 mad’arských dospelých osôb hodnotilo svoje najcharakteristickejšie každodenné ciele z hl'adiska ich náboženských dôvodov (NRM a TRM) a pozitívne a negatívne emócie s nimi spojené, a tiež skóroval ich spokojnost', úroveň sebarealizácie a zmysluplnosti týkajúce sa týchto cielov. Výsledky ukazujú, že NRM sa spájalo s negatívnymi emóciami, zatial' čo TRM sa viac spájalo s pozitívnymi emóciami. Okrem toho emočný význam projektov bol mediátorom medzi náboženskými dôvodmi a duševnou pohodou. 